\title{
O CONCEITO DE DIREITO EM HART *
}

\author{
Maria da Glória Lins da Silva Colucci
}

\section{INTRODUÇAOO}

A obra compreende deZ capítulos, dispostos, em suas linhas gerais, da seguinte forma: do primeiro até ao quinto capítulo o autor apresenta as diversas propostas ou teorias que pretendem enunciar o conceito de direito; do quinto capítulo em diante, após tecer críticas que lhe parecem pertinentes, HART propõe um ponto de partida para a elaboração daquele conceito, baseando-se na icéia de sistema, e o desenvolve até o ultimo capítulo, quando considera o Direito Internacional.

No prefácio afirma o autor que pretende em sua obra comprender o direito, a coerção e a moral, enquanto fenômenos sociais diferentes, ainda que relacionados. Afirma que se trata de um ensaio de teoria jurídica analítica, onde almeja classificar o pensamento jurídico, sem, todavia, deixar de lado o problema do significado dos termos para alcançar os fenômenos (o que ele denomina de sociologia descritiva), mas que tem muito a ver com as tendências de enfocar o direito lingüisticamente.

Buscando guardar coerência com seu próprio pensamento. HART poucas citações faz no corpo do trabalho, remetendo sempre - leitor às notas de rodapé ou ao final do livro onde estão as NOTAS. Justifica esta metodologia por se tratar de uma obra didática, preparada também para os que se iniciam no estudo do direito.

Quanto à forma de apresentação, os capítulos são quase que todos divididos em subtópicos, onde o autor gradativamente desenvolve a temática proposta e sempre, ao terminar o capítulo, apresenta conclusões. $\mathbf{E}$ obra de fácil entendimento, todavia, por ser alentada e escrita em língua estrangeira, torna-se, num primeiro momento, demorada sua leitura.

- Análise feita com base na obra El Concepto de Derecho de H. L. A. HART, tradução de Genaro R. Carrió, publicada pela Editora Nacional. México, 1978, 331 páginas.

- Trabalho apresentado à disciplina de Teoria Geral do Direito, no Mestrado em Direito da Universidade Federal do Paraná, sob a orientação do professor Ivan Guérios Curi, 1987. 
A clareza, lógica e exemplos dados são o ponto forte de seu trabalho, demonstrando o autor uma grande preocupação em encontrar na realidade jurídica concreta, ou melhor, onde o direito se aplica e se estuda, uma resposta que permita construir um conceito de direito.

HART vincula-se à jurisprudência analíica dos ingleses, como ele mesmo declara no prefácio, todavia, não é dos mais extremacos, posto que lança questionamentos que não se resumem ao âmbito exclusivo da ciência do direito. 


\section{CAPITULO I}

\section{PERGUNTAS PERSISTENTES}

Em nenhuma área do saber humano há tanta preocupação com a pergunta "O que é?" como acontece com o saber jurídico. For isso mesmo é que se tem encontrado tantas respostas que, embora contraditórias, foram esclarecedoras, a seu tempo, do conceito de direito.

Se conceituar o direito é difícil, exemplificá-lo não o é, tanto que o leigo sabe que há sistemas jurídicos, juízes, tribunais, que devemos indenizar os danos causados, observar normas para fazer um testamento e assim por diante. Se todos sabem disso, porque então permanece a pergunta: O QUE É O DỉREITO? Não seria pelo fato de que além dos casos típicos, em que todos concordam que é direito, não haveria outros tantos duvidosos? No direito primitivo e no direito internacional são comuns casos que oferecem dúvidas, porque o primeiro carece de leis, e o segundo difere daquilo que normalmente se tem como próprio, característico do direito.

Na verdade, a perplexidade quanto ao conceito de direito tem sido causada pelas questões ou temas que poderiam ser chamadus de recorrentes, que envolvem três ordens: $1 .{ }^{\mathrm{a}}$ ) o fato de que a ordem jurídica estaria respaldada em ameaças, o que constituiria para alguns (como AUSTIN) a "chave da ciência do direito", denominadas tais ordens de "command" (pág. 8); 2.a) as nomas morais e 0 direito guardam entre si estreitas ligações, que vão desde o uso de certos vocábulos (como obrigações, deveres) até o combate à violência, ao homicídio etc. Como distinguir, então, o direito e a moral?; $3 .^{a}$ ) que o direito se enuncia por regras é outro pensamento frequente entre os doutrinadores, no entanto, indaga-se: Como são tais regras? As regras são de natureza diversa; algumas fixam comportamentos, outras procedimentos. A difererça crucial estaria em que as regras jurídicas e outras estão distanciadas pelo "ter que" e o "dever", e as conseqüências que acarreta o seu descumprimento. A pré-determinação do castigo não é aspecto, no entanto, tão importante para caracterizar as normas jurídicas, sobretudo se considerarmos que o papel do juiz ao apiicá-lo é de tomar a norma como guia e a transgressão como razão ou justificativa do castigo (Pág. 13). 
Isto posto,..os três problemas recorrentes são: Em que se diferencia o direito das ordens respaldadas em ameaças e que relações tem com elas? O que distingue a obrigação jurídica da obrigaçao moral e que relação tem com ela? O que são regras e em que medida o direito é uma questão de regras? (Pág. 16).

A definição do direito está ligada a estas três ordens de perguntas. $\mathrm{O}$ autor não se propõe a definir o direito, nem muito menos c que seja "sistema jurídico", mas tem por objetivo "avanȩar a teoria jurídica proporcionando uma análise elaborada da estrutura distinta de um sistema jurídico nacional, e uma melhor compreensão das semelhanças e diferenças entre o direito, coerção e moral, como tipos de fenômenos sociais" (Pág. 21).

Lançadas as três questões recorrentes e deixando claro que o direito está ligado a outras ordens de indagações que envolvem a moral e o meio social, o autor passa ao capítulo seguinte.

\section{CAPITULO II}

\section{NORMAS JURÍDICAS, MANDADOS E ORDENS}

AUSTIN em sua obra THE PROVINCE OF JURISPRUDENCE DETERMINED analisou os "command" (mandados) e hábitos e o mesmo faz HART, ainda que por outros caminhos, para chegar ao que é o direito. Assim desenvolve seu racionínio:

Os modos imperativos são comuns em todas as línguas quando se quer que alguém faça ou deixe de fazer algo (Vá pra casa; venha aqui...). Por outro lado, as palavras ordem e obediência sugerem a idéia de autoridade e respeito, assim o autcr utilizará a expressão "ordens respaldadas em ameaças" e "ordens coercitivas", para referir-se às ordens que têm apoio em ameaças e cujo cumprimento também está ligado às palavras obediência e obedecer (pág. 25).

De todas as variedades de normas jurídicas a que mais se assemelha à "ordem respaldada em ameaças" é a lei penal. O controle jurídico se manifesta, na grande maioria das vezes, pelo fato de que é geral e que dita comportamentos, e não apenas se $d i$ rige a toda comunidade como pretende AUSTIN (pág. 28). As normas jurídicas têm como características a permanência ou persistência e a crença de que sua desobediência acarretará a execução da ameaça que nela se contém.

Por outro lado, a idéia de sistema jurídico está ligada à independência e supremacia de um soberano dentro de um determinado território (a exemplo da Rainha na Inglaterra), o que 
conduz à seguinte conciusão:... "em qualquer lugar onde haja um sistema jurídico é necessário que exista alguma pessoa ou corpo de pessoas que emitam ordens gerais, respaldadas em ameaças e que estas ordens sejam genericamente obedecidas, existindo a crença generalizada de que estas ameaças serão provavelmnte tornadas efetivas ocorrendo desobediência. Esta pessoa ou corpo deve ser internamente supremo e externamente independente" (tradução livre, pág. 32).

\section{CAPfTULO III}

\section{A DIVERSIDADE DE NORMAS JURIDICAS}

Ao compararmos a diversidade de normas jurídicas que aparecem nos sistemas modernos de direito, verificaremos que nem todas ordenam fazer ou deixar de fazer algo. Podemos constatar n costume, que ocupa lugar modesto, porém genuíno, na maior parte dos sistemas jurídicos.

Há três ordens de objeções à noção de "ordens respaldadas por ameaças": as que dizem respeito ao conteúdo das normas jurídicas; âmbito de aplicação e modos de origem.

\section{a) CONTEÚDO}

Se podemos estabelecer analogia entre a noção de "ordens respaldadas por ameaças' e as normas penais, bem como com a responsabilidade contratual, há, no entanto, classes de normas jurídicas que, na verdade, outorgam poderes ou estabelecem facilidades aos particulares para que levem a cabo seus intentos. (pág. 35). Há normas que conferem tais poderes aos particulares (como no caso dos testamentos, dos contratos) e outras que outorgam poderes aos funcionários públicos, para que façam funcionar, por exemplo, os tribunais. Assim, há normas que especificam o objeto ou conteúdo da jurisdição, outras que especificam o modo de investidura e estabilidade na função, outras cstabelecem procedimentos (pág. 37). Também no exercício dos poderes legislativos há regras que se não enquadram nas "ordens respaldadas em ameaças".

A radical diferença de função entre estas normas e as de natureza penal é que impede o uso de uma terminologia única. O autor afirma que sua classificação - normas que conferem poderes e normas que impõem deveres - é tosca, porém é uma primeira tentativa de estabelecer a diferença entre as duas espécies de normas (Pág. 40). 
O desejo de uniformidade é muito forte na teoria jurídica, de modo que alguns chegam a demonstrar que "a noção de ordens respaldadas por ameaças" é adequada para a análise das regras que conferem poderes, como é para as de direito penal, posto que... "em ambos os casos as ações poçem ser criticadas ou valoradas, com referências às regras, como juridicamente corretas ou incorretas... e constituem "pautas ou critérios de conduta" (standards) para a apreciação crítica de ações determinadas" (Pág. 41).

Concluindo, poder-se-ia dizer,... "à custa de alguma impropriedade, que enquanto as regras semelhantes às do direito penal impõem deveres, as regras que ccnferem poderes são fórmulas para a criação daqueles" (Pág. 42).

$\mathrm{O}$ primeiro argumento aue mestra identidare fundamental entre as duas classes de normas é a nulidade, que ocorre quando näo é satisfeita alguma condição essencial ao exercício do poder. Outros consideram as normas que conferem poderes como "fragmentos de normas jurídicas"'. De acordo com este entendimento (como o de KELSEN)... "Todas as normas genuinas, segundo este modo de ver, são ordens condicionais aos funcionários para que apliquem sanções. 'lodas têm esta forma: "Se se faz, omite ou ocorre algo do gênero $\mathrm{X}$, então se aplica uma sanção do gênero Y (Pág. 45).

Para esta última teoria, o importante é que haja sempre uma sanção prescrita para a transgressão em cada norma, dirigidas ao funcionário responsável por sua aplicação; ao passo que na outra concepção do direito como "ordens respaldadas en ameaças", as normas são dirigidas aos cidadãos em geral e não apenas aos funcionários.

Não resta a menor dúvida de que o que o cidadão precisa fazer para cumprir as normas é uma indagação importante; também o que os tribunais decidem é significativo, porém não se pode reduzir o direito ao aus se passa nos tribunais. O direito como meio de controle social deve ser visto "nas diversas formas em que é usado para contr Jlar, guiar e planejar a vida fora dos tribunais" (Pág. 51).

A forma menos extremada ca teoria deixaria intactas as normas jurídicas penais e todas as outras que impõem deveres, posto que elas se conformam com o modelo simples das ordens coercitivas, porém as normas que conf $€$ rem poderes jurídicos e definem o modo de seu exercício teriam que ser reduzidas a esta única forma.

Para alguns as regras que conferem e definem poderes legislativos e judiciais são, como já foi dito, meros fragmentos de normas juríd:cas; no entanto, o que conduziu o mundo pré-jurídico ao mundo jurídico foi justamente a introdução na sociedade de 
regras que habilitam os legisladores reformar e criar regras de dever, bem como outras regras oue os juízes devem observar para verificar se as primeiras foram transgredidas, por isto tais normas não podem ser consideradas como meros fragmenos de normas jurídicas (Pág. 52).

\section{b) O AMBITO DE APLICAÇĀO}

O âmbito de aplicação de uma norma jurídica é sempre uma questão de interpretaçãc do preccito. Ao interpretá-lo pode-se incluir ou excluir aqueles que o ditaram e, por via de conseaüência, hoje se aprovam muitas leis que impõem obrigações jurídicas aos seus autores (Pág. 53).

A imagem vertical do direito de "cima para baixo", tão atrativa em sua simplicidade, somente poderá ser entendida se separarmos a figura do legislador $\mathrm{em}$ sua capacidade oficial e a pessoa do legislador em sua capacidade particular (pág. 54). Se usarmos a figura da promessa, que é bem melhor do que o das ordens coercitivas, poder-se-á entender que o legislador também está dentre aqueles a quem se dirige a promessa (prevista $\mathrm{cm} \mathrm{lei).} \mathrm{Na}$ verdade o legislador não é aquele que dá ordens a outro, que está por definição fora do alcance do que o faz, mas frequentemente, à semelhança do que promete, exerce poderes conferidos por regras e como promitente, deve estar dentro deste âmbito.

\section{c) MODOS DE ORIGEM}

Até agora foram analisadas apenas as leis que têm analogia com as ordens coercitivas, e para seus adeptos toda norma deve ser considerada com resultante de um ato de criação jurídica. E o costume?

O costume é o tipo de norma que mais contradiz este tipo de pretensão: Indaga-se: o costume é direito? Principalmente será cabível esta dúvida se verificarmos que há muitos costumes que não são direito. Para que seja costume jurídico é preciso que tenha sido reconhecido. Como ocorre este reconhecimento? Somente quando alguém, talvez o soberano, tenha estabelecido que o costume tem reconhecimento jurídico, o que se assemelha em muito ao ato de legislar?

Como adquirir o status jurídico? Para expor a teoria do reconhecimento juridico é preciso analisar o papel do soberano que dita normas e do subordinado que dá ordens em seu nome. No primeiro caso o direito decorre da ordem do soberano, no segundo será ordem se decorrer expressa ou tacitamente do que foi ordenado pelo soberano. Assim, enquanto os tribunais não aplicam o costume este é simples costume, sem status jurídico, uma vez aplicado é reconhecido juridicamente. Esta teoria, no entanto, deve sofrer duas críticas, pelo menos: 
1a) Não é necessariamente verdade que enquanto as regras consuetudinárias não são usadas nos litígios carecem de status como direito;

2a) É possível considerar a não interferência do soberano (entendido no Estado Moderno o poder legislativo ou o eleitorado), que nem sempre tem tal conhemento, consideração ou decisão d€ não interferir)como a expressão tácita do desejo de que a regra seja obedecida? (Págs. 58-59).

Em que consiste, então, o reconhecimento jurídico? Se não é a ordem do tribunal que lhe dá tal status, nem a ordem tácita do supremo poder criador do direito? Como pode ser direito semelhante à lei antes de ter sido aplicado pelos tribunais? As respostas serão dadas oportunamente.

Isto posto, HART chega às seguintes conclusões:

1a) A concepção do direito como ordens coercitivas enfrenta desde o comcço a objeção de que há variedades de normas jurídicas, que não correspondem àquelas descrições;

$\left.2^{\mathrm{a}}\right)$ A idéia de mal ameaçado ou sanção foi ampliada até se incluir a nulidade e a noção de regra jurídica foi restringida a ponto de se excluirem as que conferem poderes, como meros fragmentos de normas;

3a) Para explicar a auto-obrigatoriedade das normas se descobriram no legislador duas pessoas; uma oficial (o legislador mesmo) e outra particular (a quem a norma também obriga);

4a) A noção de ordein foi €stendida desde a expressão verbal até u expressão tácita de vontade, que consiste na não interferência com ordens dadas por subordinados;

5a) O modelo clas ordens respaldadas em ameaças obscurece mais do que esclarece;

6a) A uniformidade no que toca ao direito pode ser um erro, porque a característica que o distingue é justamente a fusão de tipos diferentes de regras (Pág. $61)$. 


\section{SOBERANO E SÚDITO}

A teoria do soberano pode ser delineada da seguinte forma: em toda sociedade onde há direito há um soberano, entendido como uma pessoa ou um grupo de pessoas cujas ordens são habitualmente obedecidas pela grande maioria da sociedade e que não obedece habitualmente a nenhuma outra pessoa ou pessoas.

HART considera em relação à teoria do soberano o seguinte: 19) o hábito de obediência e o caráter contínuo da autoridade e a persistência das normas mesmo depois de ter desaparecido quem as elaborou; 29) a posição do soberano em relação ao direito (Pág. 64).

Quanto ao hábito de obediência pode ser entendido em relação a certas normas jurídicas, porém quando as leis obrigam, por exemplo, ao pagamento de impostos, desaparece a espontaneidade, que caracteriza o hábito.

Assim, a comunidade constitui alguém como seu soberano quando há o hábito de cbediência às suas ordens. Se a comunidade tem um Rei e regras de sucessão, não fica tão difícil entender este hábito de obediência, porém, numa democracia moderna cs membros do legislativo mudam frequentemente, de modo que fica uma dúvida quando à continuidade do poder de criação do direito ao longo de uma sucessão de legisladores individuais. Se, no entanto, levarmos em conta que há regras quanto à sucessão, tanto no primeiro caso, quanto no segundo, poderemos entender porque a obediência continua.

Há diferenças entre hábito e regra, que podem ser reunidas em três ordens:

1a) Para que o grupo tenha um hábito é preciso que sua conduta seja efetivamente convergente e o desvio não cause críticas;

2a) Para que haja uma regra é preciso que exista uma minoria que a transgrida e que se negue a aceitá-la como uma pauta ou critério de conduta para si ou para os demais e que este comportamento gere críticas e a reafirmação de que a regra é necessária (Pág. 70);

3a) As regras sociais se distinguem dos hábitos pelo aspecto interno, ou seja, uma atitude crítica, de reflexão quanto às regras em si mesmas, ligadas às idéias de correto e incorreto (Pág. 72). 
Finalmente, os funcionários do governo manifestam sua aceitação quanto às regras, aplicando-as; ao passo que o cidadão comum pela simples aquiescência quanto aos resultados dos atos oficiais.

Por que o direito persiste mesmo através dos séculos, sendo cumpridas suas regras? Como o direito criado por um legislador antigo, já desaparecido, ainda continua obrigando? "HOBBES, seguido por BENTHAN e AUSTIN, disse que 'o legislador não é aquele sob cuja autoridade a lei foi feita pela primeira vez, senão aque!e por cuja autoridade continua sendo hoje lei" (Pág. 79). Esta afirmação é enganosa, porque se baseia na teoria de que a obediência habitual ao soberano presente é que justifica a persistência das normas jurídicas. Também é errônea a teoria que afirma que nada é direito até que seja aplicado por um tribunal (realismo jurídico), já que não explica porque uma lei antiga ainda está em vigor e urna recentemente promulgada não é aplicada (pág. 82) e, muito menos a persistência do direito; porque ou ambas as leis não são leis antes de serem aplicadas pelos tribuna's a um caso particular, ou sãc lei mesmo sem serem aplicadas. (Pág. 82).

Um outro ponto que merece atenção de HART é o das limitações juridicas ao poder legislativo. Na teoria do soberano o hábito geral de obediência do súdito tem, como complemento, a ausência de tal hábito por parte do soberano. Não há, para seus defenscres, limite algum ao poder criador do soberano, entendidos limites jurídicos, posto que outros limites (de natureza política, por exemplo) sāo admitidos. No entanto, a existência de um soberano com poderes jurídicos ilimitados não é condição para que exista o direito, sobretudo se considerarmos que em muitos Estados Modernos há limitações jurídicas aos poderes de legislar, previstas no texto constitucional, ou mesmo sendo retiradas certas áreas de competência de um poder e dando-as a outro.

$\mathrm{Na}$ verdade, pondera HART, as chamadas limitações jurídicas à autoridade legislativa, ..."não consistem em deveres impostos ao legislador de obeçecer a algum legislador superior, senão $\mathrm{\epsilon m}$ incompetências estabelecidas em regras que o habilitam para legislar" (Pág. 87).

Para demonstrar que estamos diante de um sistema jurídico independente não é necessário que seu legislador supremo tenha poderes ilimitados ou que não obedeça habitualmente a ninguém. "Há que se demonstrar, simplesmente, que as regras que habilitam o legislador não conferem autoridade superior a quem tem também autoridade sobre outro território" (Pág. 88).

No mundo moderno há muitos sistemas jurídicos em que o corpo que é considerado o "legislador supremo do sistema" está submetido a fımitações jurídicas no exercício de seus poderes le- 
gislativos, de modo que se pretendemos falar de um soberano com poderes ilimitados, temos que identificá-lo por trás do poder legislativo juridicamente limitado" (Pág. 89).

Para AUSTIN são os eleitores que representam o poder soberano (pág. 92). Assim, o eleitorado é o legislador extraordinário e ulterior, superior ao legislador ordinário (Poder Legislativo) que está submetido a limitações jurídicas. HART critica esta idéia de soberano, afirmando que a noção de soberano, como uma pessoa, desaparece totalmente e que, na verdade, a continuidade leg:slativa somente se entende a partir de uma norma por todos aceita; sobretudo se considerarmos que o "grosso da sociedade" nem sempre vota e que a idéia de obediência e de outros que obedecem desaparecia porque toda a sociedade ordena a si mesma e a si mesma obedece (Pág. 94). Por fim, a soberania sendo atribuída ao eleitorado enfrenta uma giave dificuldade onde não há eleitorado.

Os equívocos desta teoria são demonstrados por HART mais com o objetivo de evidenciar que as idéias de ordem, hábito e obediência não são adequadas para a análise do direito. Ressaltando que o que falta é a noção de regra que confere poderes, que podem ser limitados ou ilimitados, a pessoas que reúnem certos requisitos para legislar mediante a observância de certo procedimento (Pág. 96).

\section{CAPfTULO V}

\section{O DIREITO COMO UNIÃO DE REGRAS PRIMÁRIAS E SECUNDÁRIAS}

$\mathrm{O}$ autor propõe, a partir do Capítulo $\mathrm{V}$, um novo ponto de partida para a construção do conceito de direito, posto que as ordens respaldadas por ameaças; as ordens coercitivas do soberano e outras fracassaram em seu intento porque “... as idéias de ordens, obediência, hábitos e ameaças, não incluem, nem tão pouco podem produzir mediante sua combinação, a idéia de regra, sem a qual não podemos abrigar a esperança de elucidar nem sequer as formas mais elementares de direito..." (Pág. 101).

O seu ponto de partida é, portanto, a existência de dois tipos de normas as primárias (que prescrevem que os seres humanos façam ou omitam certas ações quer queiram ou não) e as secundárias (que estabelecem que os seres humanos podem, fazendo ou dizendo certas coisas, introduzir novas regras do tipo primário, extinguir ou modificar regras anteriores, ou determinar de diversas maneiras o seu efeito, ou controlar sua atuação). Em 
sintese as do primeiro tipo impõem deveres; as do segundo conferem poderes, públicos ou privacios (Pág. 101).

Da combinação desses dois tipos de normas surge para HART a verdadeira chave da jurisprudência e não, como afirmou AUSTIN, nas ordens coercitivas. A união dos elementos que compõem os dois tipos de normas citadas é o ponto central para a elucidação da estrutura do pensamento jurídico (Pág. 102).

A idéia de que onde há normas jurídicas a conduta se torna obrigatória e não optativa é importante para se entender a interação entre normas primárias e secundárias, destacando-se que há diferença entre se ver obrigado a e ter obrigação de, porque ... "Sem dúvida, é crucial para compreensão da idéia de obrigação advertir que nos casos individuais o enunciado de que uma pessoa tem uma obrigação segundo certa regra, e a. predição de que provavelmente haverá de sofrer um castigo por causa da desobediência, podem não coincidir" (Pág. 106). A idéia de ter obrigação vu submeter-se a uma obrigação envolve outra: a da existência de uma regra. Por outro lado, ... "a importância ou seriedade da pressão social que se encontra por trás das regras é o fator primordial que determina que sejam concebidas como dando origem a obrigações" (Pág. 108).

O aspecto interno das regras é importante para que se alcance o sentido proposto pelo autor, porque implica em considerar a mancira como o grupo contempla sua própria conduta, ao passo que do ponto de vista externo apenas se vislumbra a maneira como as regras funcionam na vida dos membros do grupo (pág. 112). Assim, a violação de uma regra não é apenas uma base para a predição de que sobrevirá certa reação hostil (conforme pretende a teoria da predição ou da probabilidade do castigo), mas uma razão para esta hostilidade (Pág. 113). Assim, podem as regras ser vistas sob o aspecto externo como sinais de um possível castigo, ou sob o ponto de vista interno, como pautas ou modelos para as condutas individuais. A crítica de HART ao pensamento de AUSTIN é justamente no ponto em que despreza o aspecto interno das regras obrigatórias (Pág. 113).

Examinando os elementos do direito, parte o autor da suposição de que é possível uma sociedade sem tribunais, juízes ou funcionários de algum tjpo, como acontecia em comunidades primitivas, onde o único meio de controle social era justamente a atitude geral do grupo face a suas pautas ou critérios de comportamento, que são jdentificados por HART como regras primá. ras de obrigação (pág. 114). É óbvio que tais regras assim agrupadas não constituirão um sistema, e apresentarão graves deficiências quanto à identificação de quais são as normas e como aplicá-las. seu defeito principal será a falta de certeza (pág. 115). $\mathrm{O}$ segundo defeito, o caráter estático das regras, resulta do fato 
de que somente se modificarão pelo lento processo de crescimento; o terceiro defeito será a ineficiência da difusa pressão social exercida para fazer cumprir as regras (Pág. 116).

Como solucionar estes três defeitos principais de uma estrutura social baseada apenas em regras primárias de obrigação? Somente com as regras secundárias que são de um tipo diferente. De tal sorte que o direito ..."pode ser caracterizado em sua forma mais esclarecedora como a união de regras primárias de obrigação como estas regras secundárias" (Pág. 117).

a) Para resolver o problema da falta de certeza que o regime de regras primárias apresenta, propõe o autor uma regra de reconhecimento (rule of recognition), entendida com a "que especificará alguma característica ou características cuja posse por uma regra sugerida é considerada como uma indicação afirmativa, indiscutível de que se trata de uma regra do grupo, que há de ser sustentada pela pressão social que este exerce"... (pág. 117). O importante de tal regra de reconhecimento é que é revestida de autoridade, vale dizer, como a forma própria de resolver as dúvidas acerca da existência da regra: em um sistema jurídico mais desenvolvido, as regras de reconhecimento são mais complexas:... "em lugar de identificar as regras exclusivamente por referência a um texto ou lista, elas o fazem por referência a alguma característica geral possuída pelas regras primárias" (Pág. 118). "Ao proporcionar uma marca ou sinal de autoridade, introduz, ainda, que em forma embrionária, a idéia de um sistema jurídico. Porque as regras não são mais um conjunto discreto inconexo, senão que, de uma maneira simples, estão unificadas" (Pág. 118).

b) O remédio para a qualidade estática do regime de regras primárias consiste na introdução do que HART denomina "regras de mudança ou modificação", como por exemplo, as que permitem que um indivíduo ou um corpo de invidíduos introduzam novas regras primárias para a condução da vida en grupo, revogando as já existentes. Somente assim se pode entender as idéias de criação e derrogação das normas jurídicas por via legislativa. Há, necessariamente, uma conexão muito estreita entre as regras de modificação e as 
regras de reconhecimento... "porque onde existem as primeiras, as últimas necessariamente incorporam uma referência à legislação como característica identificatória das regras, ainda que não mencionem todos os detalhes do procedimento legislativo" (Pág. 119).

c) Para remediar a insuficiência da pressão social difusa, as regras secundárias determinam, revestidas de autoridade, se em uma ocasião particular se transgrediu cu não uma regra primária (pág. 120), sâo chamadas, neste caso, de regras de julgamento, porque além de identificar os indivíduos aue podem julgar, tais regras definem também o procedimento a seguir (Pág. 120). São normas que conferem poderes jurisdicionais, definem um grupo importante de conceitos jurídicos: juiz, tribunal, jurisdição e sentença (Pág. 120).

Conclusão: Temos:

regras primárias de obrigação.

regras secundárias:

- reconhecimento e julgamento

- modificação

A uniâo de regras primárias e secundárias está no centro de um sistema jurídico, porém não é tudo e à medida que nos afastamos do centro teremos que identificar e ubicar em outras formas que serão em outros capítulos examinadas.

\section{CAPfTULO VI}

\section{OS FUNDAMENTOS DE UM SISTEMA JURÍDICO}

Os fundamentos de um sistema jurídico estão na regra secun dária de reconhecimento que identifica as regras primárias de obrigação. Os critérios de autoridade podem ser, por exemplo: referência de um texto revestido de autoridade, uma sanção legislativa, a prática consuetudinária, declarações gerais de pessoas especificadas, decisões judiciais passadas, ditadas em casos particulares (Pág. 126).

Nos sistemas jurídicos modernos, onde há uma variedade de fontes, HART ressalta que se torna mais complexo o problema da regra de reconhecimento e normalmente incluem uma constituição escrita, a sanção pelo poder legislativo e os precedentes judiciais (Pág. 126). 
Na vida cotidiana de um sistema jurídico sua regra de reconhecimento raramente é formulada de forma expressa como uma regra (pág. 127); destacando-se que tal regra tem um enunciado interno (que decorre de sua aplicação e aceitação) e um enunciado externo (que implica em detectar-se que ela existe, mesmo que não seja aceita) (Pág. 128).

Através da regra de reconhecimento fica fácil resolver o problema da validez juridica porque, segundo HART: "Dizer que uma determinada regra é válida é reconhecer que ela satisfaz todos os requisitos estabelecidos na regra de reconhecimento e, portanto, é úma regra do sistema" (Pág. 129).

Um dos problemas intrincados, vinculado à idśia de validez jurídica, é o da relação entre validez e eficácia do direito. Assim, afirma HART... "seria errôneo dizer que os enunciados de validez "significam" que o sistema é geralmente eficaz:" (entendida eficácia como sua efetiva observância pelo grupo, segundo HART) . (Pág. 130).

É a "regra de reconhecimento que fornece os critérios para determinar a validez de outras regras do sistema, na verdade é a regra última (pág. 132). A regra de reconhecimento é o critério supremo e a regra última do um sistema jurídico. A idéia de supremo não se confuncie com ilimitado, porque a regra última pode conter em si mesma limitações de ordem juríd ca (como acontece nas Constituições), quando proíbe emendas ao texto, ou coloca fora do alcance do legislador alterar certos aspectos considerados fundamentais (pág. 133). Para o direito inglês, a regra última seria o que a rainha no parlamento sanciona é direito.

A regra de reconhecimento não é uma hipótese, segundo HART, porque ela é aceita e posta em prática, єm ๖ora seja uma questão complexa determinar o que seja a regra de reconhecimento. A regra de reconhecimento não pode ter "sua validez admitida" ou "pressupor-se sua existência", porque ela efetivamente existe. A validez é determinada pelo €nunciado interno, e sua eficácia pelo externo.

"A afirmação de que ela existe só pode ser um enunciado de fato externo... "a regra de reconhecimento somente existe como uma prática complexa, porém normalmente concordante, dos tribunais, funcionários e particulares, ao identificar o direito por referência a certos critérios. Sua existência é umá questão de fato (Pág. 137).

A regra de reconhecimento é direito porque traz em si as características definitórias do sistema jurídico, não tendo portanto outra natureza; além do mais é fato, porque afirmamos que existe e que serve para identificar as demais como válidas, e participantes de um sistema eficaz (Pág. 139). 
O que é um sistema jurídico em HART?... é nada mais nada menos do que "a união complexa de regras primárias e secundárias... (pág. 142). Quais as condições mínimas que uma sociedade precisa para ter um sistema jurídico? (Pág. 140) - Há duas condições necessárias e suficientes ou mínimas para a existência de um sistema jurídico: $1 .^{2}$ ) as regras de condutas válidas, segundo o critério de reconhecimento, tem de ser geralmente obedecidas; $2 .^{a}$ ) e as regras de reconhecimento que especificam os critérios de validez jurídica, suas regras de modificação e julgamento, têm de ser efetivamente aceitas pelos funcionários como pautas ou modelos públicos e comuns de conduta oficial (Pág. 145).

Conclusão: "A afirmação de que um sistema jurídico existe é, portanto, um enunciado bifronte, uma de cujas caras mira a obediência por parte dos cidadãos comuns, e a outra a aceitação de regras secundárias como pautas ou critérios comuns críticos de conduta oficial, por parte dos funcionários" (pág. 145).

Haverá uma patologia no sistema jurídico quando há um divórcio entre o setor oficial e o setor privado, no sentido de que já não há uma obediência generalizada às regras que são válidas segundo os critérios de validez usados pelos tribunais (pág. 146).

Tal ruptura pode ser resultante de diferentes fatores ie perturbação, casos, como o da revolução, invasão ou quando ocorre a simples quebra do controle jurídico ordenado, diante da anarquia ou do banditismo que não tem pretensões políticas de governar (pág. 147).

Um outro caso que pode demonstrar uma patologia no sistema jurídico é aquele em que há quebra da unidade entre os funcionários. "Pode ocorrer que com relação a certas questões constitucionais, e unicamente em relação a elas, exista uma divisăo dentro do mundo oficiai que conduza, em definitivo, a uma divisão do poder judicial" (pág. 151).

Finalmente, quanto à validade de se estruturar um sistema a partir de uma regra, afirme-se que sempre haverá uma sombra de dúvida, quando se compara esta regra e casos particulares. Seus críticos afirmam que sempre se incorrerá no vício do conceptualismo ou formalismo.

Por outro lado, "quando as decisões do tribunal são consideradas precedentes, a especificação do standard variável contido neles se assemelha muito ao exercício do poder de elaborar regras delegadas a um corpo administrativo, ainda que haja diferenças óbvias" (pág. 165). 
A comparação destas duas técnicas nos mostra que têm falhas: no caso da Legislação o standard é menos variável, ao passo que no do precedente é mais variável. No caso do precedente também há uma certa abertura, porque o juiz ao comparar o caso presente com o anterior implica em estabelecer alguma diferença juridicamente relevante entre aquele e este caso presente, e a classe de tais diferenças nunca pode ser determinada de forma exaustiva (pág. 168). O que implica em ampliar a regra. No entanto, o precedente, pelo menos no caso inglês, tem estabelecido um tal número de regras que são "tão determinadas como qualquer regra contida em uma lei” (Pág. 168).

O que quer dizer "textura aberta do direito" em HART? ... significa aue há, por certo, áreas de conduta onde muito deve deixar-se para que seja desenvoivido pelos tribunais ou pelos funcionários que procuram achar um compromisso, à luz das circunstâncias, entre os interesses em conflito, cujo peso varia de caso para caso" (pág. 168).

Há diversidade, no entanto, de ceticismo em relação às regras, há os que negam que um sistema jurídico seja estruturado a partir de regras, sendo certo para tais teóricos que o direito é unicamente expressão das decisões dos tribunais (pág. 170). Uma outra forma mais atenuada admite que há regras que estruturam os tribunais, e, as leis, na verdade, aparecem como simples fontes do direito, e que as leis somente serão direito se aplicadas pelos tribunais (pág. 171). Este ceticismo é mais no sentido de negar a existência de regras primárias, embora reconheça a existência das secundárias.

O ceticismo diante das regras merece sua atenção apenas no ponto em que analisa o papel das regras na decisão judicial (pág. 172), quando as vê apenas como uma maneira de predizer o que farão os juízes. Na verdade tais céticos pensam assim: "Ou as regras são o que seriam num paraíso formalista e elas sujeitam como cadeias; ou bem não há regras, senão unicamente decisčcs predizíveis ou tipos de ação prognosticável" (pág. 173). Outros negam a existência de regras obrigatórias para os tribunais, negando-se que os juízes observam as regras porque as considerem como pautas ou critérios de conduzir-se ao julgar, mas que vão mais pela sua própria intuição. Uma outra forma de ceticismo é no sentido de que a decisão dos tribunais possue um caráter único, como algo dotado de autoridade, e, quando se trata dos tribunais supremos, autoridade final (pág. 175), com os riscos que toda decisão definitiva produzida por seres humanos falíveis pode trazer. No entanto, sabe-se que tais decisões, embora falíveis, não são resultantes de arbítrio, mas de regras pré-estabelecidas para julgar, em que pese uma certa margem de flexibilidade. 


\section{CAPITULO VIII}

\section{JUSTIÇA E MORAL}

Para elucidar características distintivas do direito como meio de controle social, já ficou demonstrado que não podem ser elaroradas a partir das idéias de ordem, ameaça, obediência, hábitos e generalidade.

"O tema principal deste livro é que são tantos os atos distint vo' do direito e tantas as idéias constitutivas da estrutura do pensamento jurídico que requerem para sua elucidação a referência a um ou a ambos os tipos de regras (primárias e secundár:as), que sua união pode ser considerada com justiça como a escência do direito, ainda que os dois tipos de regras nem sempre apareçam juntos onde quer que se use corretamente a palavra dire:to" (pág. 193).

Neste capítulo HART examina a questão do imperativo e as frecüentes afirmações de que para se chegar ao conceito de direito é preciso ser considerada, como tema central, a relação neces. sária entre Moral e Direito. Há, no entanto, muitas interpretações das palavras "necessária" e "Moral".

Preocupa-se HART em identificar alguns problemas, confund'dos de há muito, do que propriamente descrever as inúmeras teor:as que se preocupam e se preocuparam com as relações entre Moral e Direito.

O primeiro problema é o da justiça; o segundo envolve as características que distinguem as regras e princípios morais, não somente em relação às regras jurídicas, mas também de outras formas de regras sociais ou critérios de conduta (pág. 195) e finalmente um terceiro problema: os diferentes sentidos e maneiras em aue se pode dizer que as regras jurídicas e a moral se relacionam.

Principios de justiças "justo" e "injusto" são formas mais específicas de crítica moral do que "bom e mau ou correto e incorreto", assim afirma HART que se pode sustentar que uma "norma jurídica é boa porque é justa, ou má porque é injusta, porém não que é justa porque é boa, ou injusta porque é má" (Pág. 197).

$\mathrm{Na}$ verdade, o princípio latente nas diversas aplicações da palavra justiçá é de igualdade e desigualdade, portanto que a idéia de justiça está ligada às de equilíbrio e proporção, e seu preceito principal é "tratar os casos semelhantes de igual modo" e for via de conseqüência "tratar os casos diferentes de maneira d ferente" (pág. 198).

Fsta conclusão, no entanto, não é suficiente, segundo HART é preciso saber quando, para os fins que se tem em mente, os ca- 
sos hão de ser considerados iguais e que diferenças relevantes apresentam entre si (pág. 199). O que revela uma certa complexidade da estrutura da idéia de justiça. Pode-se afirmar, segundo HART, que há uma nota uniforme em tal idéia: "tratar os semelhantes da mesma maneira" e um critério mutável ou variável, usado para determinar quando, para um determinado propósito, os casos são semelhantes ou diferentes" (pág. 199).

Quais as características dos seres humanos que devem ser tomadas em conta para classificarmos uma lei de "justa" ou "injusta? Estas são perguntas que estão no plano da moral e da política (pág. 201).

Os critérios de semelhanças e diferenças relevantes rodem variar a miúdo, em função do enfoque moral fundamental de uma determinada pessoa ou sociedade (pág. 202).

O fim que uma norma jurídica persegue pode aclarar seme. lhanças e diferenças que uma norma justa deveria admitir (pág. 203).

As normas jurídicas, na verdade, ou distribuem vantagens ou benefícios; ou compensam danos causados por uma pessoa a outra (pág. 204).

Pode-se observar, continua HART, que "as vezes as exigências de justiça podem entrar em conflito com outros valores..." (pág. 206) quando, por exemplo, considera o interesse geral face ao individual... $\mathrm{Na}$ verdade, em poucos momentos, há coincidência entre bem comum e individual; o que o direito faz é... "nä maior parte dos casos... estabelecer benefícios para uma classe da população à custa de privar outras do que preferem..." (pág. 207).

Termina, por definir justiça como... "a consideração imparcial de pretensões em conflito a respeito de benefícios diferentes" (pág. 208).

2. Obrigação Moral e Justiça: "A justiça constitui um segm€nto da moral que não se refere primariamente à conduta individual senão às formas como são tratadas classes de individuos" (pág. 208). A justiça é a "mais pública e a mais jurídica das virtudes. Todavia os princípios de justiça não esgotam a idéia de moral; a nem toda crítica do direito feita sobre fundamentos morais é formulada em nome da justiça" (pág. 208).

Uma primeira dificuldade é que a palavra moral também tem sua área de incerteza ou do que denomina HART, "textura aberta", no sentido de que alguns princípios ou regras seriam classificados por alguns de morais e por outros não. $\mathrm{O}$ segundo aspecto é o que envolve a relação e o grau de importância que determinado preceito moral tem com o conhecimento e a experiência humana (pág. 209). 
Primeiramente considera HART a moral sob o ângulo da moral aceita ou convencional, que corresponde às regras primárias de obrigação, que exercem sf nsível pressão social e considerável sacrifício ou interesse ou inclinação individual e seu descumprimento causa críticas (pág. 210). "Nas sociedades que desenvolveram um sistema jurídico, há, entre suas regras não jurídicas, algumas a que se atribui importância suprema, e que apesar de diferenças marcantes, têm muitas semelhanças com suas normas de direito" (pág. 212). Há em tcdas as sociedades uma parcial superposição de conteúdo entre a obrigação jurídica e a obrigação moral, embora sejam as exigências de natureza jurídica mais específicas e detalhadas... (pág. 212).

Há, sem dúvida, semelhanças notáveis entre as normas juridicas e morais o que vem demonstrar que o vocabulário que lhes é comum (deveres, obrigações) evidencia a aproximação entre ambos: $1^{\circ}$ ) - são ambas obrigatórias; $2^{\circ}$ ) regem situações que sempre se repetem ao longo da vida dos indivíduos; $\left.3 .^{\circ}\right)$ - em ambas existem proibições quanto à violéncia, proteção à propriedade e algumas exigências de honestidade e veracidade. São quatro as características relacionadas entre si que servem para distinguir a moral, não apenas das regras jurídicas, mas de outras formas de regras sociais (pág. 215):

$1^{\circ}{ }^{\circ}$ - importância: a observância de uma regra ou pauta moral é muito importante, tanto que os indivíduos se vêm forçados a sacrificar seus interesses e inclinações pessoais; são ensinados a transmití-los como algo corrente a todos os indivíduos. As demais regras sociais não têm esta importância que as regras morais apresentam. A importância não é tão essencial ao status de regra jurídica, quanto o é para o status de regra moral. Tanto que uma norma jurídica pode continuar em vigor mesmo que todos considerem que é sem importância e que deveria ser revogada (217).

2.0) - imunidade à mudança deliberada: é característico de um sistema jurídico o fato de que podem ser introduzidas novas regras e modificarem-se ou derrogarem-se as anteriores, mediante sanção deliberada, mesmo que dentro de certos limites. Ao contrário, as regras ou princípios morais não podem ser implantados, modificados ou eliminados mediante ato deliberado. De tal sorte que... "a idéia de uma legislatura moral com competência para criar e modificar a moral, tal como mediante a sanção de normas jurídicas se cria ou modifica o dirreito, é repugnante a toda noção de moral" (pág. 220).

3.0) - caráter voluntário das transgressões morais (pág. 220): No campo moral se aiguém age de um modo que não podia evitálo, não haverá responsabilidade moral para ele, e reprovar sua 
conduta seria algo moralmente errado. No caso do direito, raras vezes o fato de não poder evitar o dano ou não querer causar o dano terá excusas, exemplo típico é o caso da responsabilidade objetiva.

4.ํ) - a forma de pressão moral (pág. 222): Tem a moral uma forma peculiar de pressão. Na moral... "A forma típica de pressão consiste em apelar ao respeito face às regras, enquanto coisas importantes em si mesmas, que se presume compartido por aqueles a quem se dirige a exortação" (pág. 223). São as normas morais conduzidas mediante advertências, ao passo que as normas jurídicas vêm acompanhadis de ameaças e de temor... (pág. 223). Há também expectativas quanto ao temor e ao castigo da transgressão da norma moral, no entanto não são estas que efetivamente pressionam 0 indivíduo a agir de acordo com as normas morais.

\section{Os ideais morais e a crítica social}

A obrigação e o dever moral são o embasamento da moral social, porém não são tudo. As quatro características apontadas são de natureza formal; quanto ao aspecto material ou conteúdo, ou melhor, qual o conteúdo necessário que as regras ou pautas devam ter para serem morais, será visto neste item.

Há pensadores que incluem, além das quatro características apontadas, uma outra: que algo somente terá o status de regra moral se de algum modo atender às necessidades e interesses humanos vitais. No entanto, considera HART que há muitos princípios morais que fogem desta última característica, porque há na moral além de abrigações e deveres, o que ele denomina de ideais morais (pág. 225). Às formas primárias de moral social somam-se muitas virtudes morais que extrapolam os simples limites exigidos pelo grupo social, tais como a temperança, bondade, sacrifício em prol do interesse alheio, etc... Estes são ideais morais.

HART acrescenta ainda que... "as estruturas da sociedade, in cluída sua moral aceita, têm que satisfazer duas condições formais, uma de racionalidade e outra de generalidade (pág. 227). A primeira nos leva à análise de certos comportamentos que, em. bora moralmente aceitos, não são racionalmente desejáveis e que todos precisam se conformar às restrições que a moral impõe, para que a regra moral seja considerada como tal.

Da mesma forma que os ideais morais são para o indivíduo de grande importância, também desempenham significativo papel para mudanças, escolhas e alternativas novas para a sociedade. São justamente estes ideais que sustentam partidos políticos opostos. 


\section{CAPITULO IX}

\section{AS NORMAS JURÍDICAS E A MORAL}

\section{I - Direito Natural e Positivismo Jurídico}

Não se podem negar as relações entre moral e direito, porém não se pode aceitar que "os critérios de validez de normas particulares usadas em um sistema jurídico tenham que incluir em forma tácita se não explícita, uma referência à moral ou à justíça”... (pág. 229).

HART examina apenas dois aspectos principais que envolvem o direito e a moral: $1^{\circ}$ ) o conflito entre o direito natural e o positivismo jurírico, entendendo positivismo jurídico como a afirmação que "em nenhum sentido é necessariamente verdade que as normas jurídicas reproduzem ou satisfazem certas exigências da moral, ainda que de fato ocorra costumeiramente assim.

Após examinar as teorias clássicas do Direito Natural e outras posições mais modernas, conclui HART que o Direito Natural precisa ter efetivamente e tem um conteúdo minimo, que ele identifica com “... princípios de conc.lta universalmente reconhecidos, que têm base em verdades fundamentais referentes aos seres humanos, sua circunstância natural e seus propósitos..."; 2.0) O segundo aspectc considerado por HART é o do conteúdo mínimo do direito natural que é fixado em cinco pontos ou verdades óbvias decorrentes da natureza humana, a saber:

a) vulnerabilidade humana: As exigências comuns coo direito e da moral não consistem, em sua maicr parte, em ações, mas omissões, e essas exigêncıas são formuladas usualmente em forma negativa, como proibições. A mais importante de todas é a que proíbe matar, porque os homens estão dispostos, eventualmente, a recorrer a ataques corporais e são vulneráveis a eles (Pág. 240);

b) a igualdade aproximada: Mesmo sendo diferentes em diversos pontos, os homens guardam entre si igualdades aproximadas (necessidades co. muns, como por exemplo, todos precisam dormir), que tornam evidente a necessidade de um sistema de abstenções e concessões mútuas, que estão na base tanto da obrigação jurídica, quanto da obrigação moral" (pág. 241); 
c) altruismo limitado: dado o fato da necessidade de sobrevivência o altruismo humano é limitado. Os homens não são demônios, nem anjos, por serem um meio termo entre estes dois extremos é que se torna preciso um sistema de abstenções mútuas. "Na realidade, o altruismo humano é limitado em extensão e intermitente, e as tendên. cias são bastante freqüentes que para não serem fatais à vida social precisam ser controladas" (pág. 242);

d) Recursos limitados: Os homens precisam de alimentos, roupas e proteção e estas coisas não se encontram disponíveis em abundância ilimitada, mas são escassas. O que conduz à instituição da propriedade e regras que exijam respeito àquela. Também a divisão do trabalho e a necessidade permanente de colaboração sãci fontes de obrigaçōes (pág. 243);

e) compreensão e força de vontade limitadas: a não ser em uma sociedade com uma coesão muito grande, não faltaria quem quisesse desfrutar das vantagens e furtar-se às suas obrigações; por isso que se torna necessária uma garantia cie que aqueles que obedecem voluntariamente não serão sacrificados pelos que não o fazem. Na verdade, "o que a razão reclama é cooperação voluntária dentro de um sistema coercitivo" (pág. 245).

Estas verdades óbvias, segundo HART, não apenas revelam o que há de bom na doutrina do Direito Natural, mas "têm vital importância para a compreensão do direito e da moral, e explicam porque a definição das formas básicas de um e de outra em termos puramente formais, sem referência a nenhum conteúdo específico ou às necessidades sociais, tem resultado inadequado (Pág. 246).

Assim, para HART, ao serem estabelecidas estas verdades óbvias, não se precisa mais discutir se todo sistema jurídico tem que estabelecer sanções, embora seja um fato que tal ocorra freqüentemente. Porque, na verdade... "não há princípios estabelecidos que proibam o uso da palavra direito para referir-se a sistemas onde não existem sanções centraimente organizadas, e é razoável (ainda que não compulsivo) usar a expressão "direito internacional" para aludir a um sistema que não tenha nenhuma sançäo" (pág. 246). 
Para o autor também podemos combater a tese positivista de que o "direito pode ter qualquer conteúdo" com as verdades ou pontos óbvios destacados acima.

\section{3 - Validez jurídica e valor moral}

Em que pese que em algumas sociedades o direito tenha se' adiantado à moral aceita, o mais comum é que o primeiro siga as pegadas da segunda (Pág. 248). Tanto é que a sociedade para ser viável precisa oferecer a apenas alguns membros um sistema de abstenções mútuas, não sendo, necessário, infelizmente, que seja oferecido a todos. Ex.: em algumas comunidades africanas a morte de um negro não tem a menor importância, ou pelo menos, não tem a mesma importância que a morte de um branco.

Para que as sanções tenñam autoridade é preciso uma aceitação voluntária. Tal poder coercitivo pode ser exercido somente contra os transgressores, ou pode ser usado para subjugar e manter em uma posição de permanente inferioridade a um grupo submetido (Pág. 248).

Uma sociedade em que há direito estaremos diante de uma situação em que há aqueles que veem as regras jurídicas como pautas ou critérios de conduta que devem ser observados e outros que apenas se submetem por temerem as conseqüências. O equilíbrio ou a preponderância de uma atitude sobre a outra dependerá co. sistema, que será mais estável, se mais equitativo, e tanto menos estável e repressivo, se privilegiar um grupo em detrimento de outro.

Uma das desvantagens de uma sociedade que tem um sistema jurídico estruturado é justamente este: de ser empregado para a opressão de muitos, sem apoio do grupo, o que não é necessário, uma vez que se impõe pela força.

Assim, um sistema jurídico apresenta algumas conexões com a Moral, as quais serão examinadas em seis pontos (denominados por HART de "outras formas de conexão entre Direito e Morizi) (Pág. 250).

Dos seis pontos apenas vamos ressaltar dois, os de n. 0 e 6 : 5. $\left.{ }^{\circ}\right)$ Princípios de legalidade e justiça: "Fode-se dizer que a distinção entre um bom sistema jurídico, que concorda em certos pontos com a moral e a justiça, e um sistema jurídico que não o faz, é uma distinção enganosa, porque necessariamente se realiza um mínimo de justiça onde quer que a conduta humana seja controlada mediante regras gerais que se fazem conhecer publicamente e são judicialmente aplicadas" (Pág. 255). Tal idéia se vaseia em ponto anteriormente analisado, qual seja: se se aplica à generalidade das pessoas determinada regra, em situação igual, tal 
regra será justa. Devem observar certos requisitos, tais como, ser inteligíveis, e poder ser observadas pela maioria e, em princípio, não devem ser retroativas, aind: que excepcionalmente possam sê-lo. Obviamente essas características do controle mediante regras estão estreitamente relacionadas com as exigências de justiça que os juristas chamam de princípios de legalidade. Seria uma forma mínima de justiça - a da generalidade, denominada de justiça natural.

Conclui HART afirmando que se isto é conexão necessária com o direito e a moral, pode ser aceita, porém "é compatível com uma enorme iniquidade" (pág. 256). Tal iniquidade se evidencia no fato de que a norma pode ser geral e ter um conteúdo profundamente injusto.

6. ${ }^{\circ)}$ A validez jurídica $\in$ a resistência do direito - Os positivistas queriam em substância promover clara e honestamente a formulação das questões teoréticas e morais suscitadas pela existência de normas jurídicas particulares que são moralmente iníquas, porém que foram sancionadas na forma estabtiecida, têm um significado claro e satisfazem todos os critérios de validez reconhecidos pelo sistema (Pág. 256).

A noção de validez está ligada à de qualidade jurídica: Assim a controvérsia entre os que aceitame os que rechaçam o ponto de vista de que as regras moralmente iníquas não podem ser direito parece simples, porém não parece ter em vista o caráter geral dela.

O núcleo do problema é, para HART, uma questão mais semântica do que seja direito, de tal forma que temos dois conceitos: um mais amplo e outro mais restrito. Se adotarmos o conceito mais amplo teremos... "direito... todas as regras são válidas segundo os critérios formais de um sistema de regras primárias e secundárias, ainda quando algumas delas atentem contra a moral de nossa sociedade ou contra o que podemos considerar que é uma moral verdadeira ou esclarecida. Se adotarmos o conceito mais restrito, excluiremos do significado do direito essas regras moralmente ofensivas (pág. 259).

O conceito mais restrito não conduz a bom termo, temos que tentar resolver o problema a partir do conceito mais amplo, que abrange tanto o uso quanto o abuso, porque permite que se distinga entre validez das normas jurídicas e sua imoralidade, ao passo que o conceito mais restrito pode, em verdade, cegar-nos quanto às iníquas, peia simples afirmação de que não são direito. De sorte que é melhor reconhecermos que há regras que são direito, mesmo sendo iníquas. 


\section{CAPITULO $\mathrm{X}$}

\section{DIREITO INTERNACIONAL}

A idéia de uma união entre regras primárias e secundárias, a que se tem atribuido neste livro tanta importância, pode ser considerada como um meio termo entre posições extremas. Na verdade, afirma HART, o conceito de Direito não tem que partir da união de regras primárias e secundárias, apenas o sistema é cuue pode resultar de tal união (pág. 263). A razão está no fato de que c livro "se oferece como uma elucidação do conceito de direito, e não como uma definição de "direito". Por isto, no último capítulo, pretende o autor examinar a pretensão formulada em casos alemães, de que deverá se negar o título de direito válido a certas regras, em razão de sua iniquidade moral, ainda quando pertençam a um sistema existente de regras primárias e secundárias" (refere-se à época do nazismo) (pág. 264).

Indaga-se aqui: é realmente Direito o Direito Internacional? Sobretudo se se considerar que não há um poder legislativo, tribunais e sanções determinadas? O Direito Internacional não só carece de regras secundárias de modificação e julgamento, como também de uma norma de reconhecimento (Pág. 264).

As dúvidas que surgem baseiam-se na confrontação do direito nac'onal e do Direito Internacional, e partem, primeiramente, da idó:a do Direito como ordem respaldada em ameacas; e depois ia crenca obscura de que os Estados são fundamentalmente incapazes de serem sujeitos de obrigações jurídicas.

As perguntas do tipo: é obrigatório o Direito Internacional? ou como pode ser obrigatório o Direito Internacional? Não estão voltadas para o problema de sua aplicabilidade, mas para seu "status" jurídico-geral. Uma das fontes de dúvidas é simplesmente que o sistema não tem sanções centralmente organizadas, o aue seria reduzir o direito unicamente a ordens respaldadas em ameaças. No entanto, a agressão entre Estados é diferente da agressão entre indivíduos; a desigualdade entre os Estados também é outro aspecto, por isso que o Direito Internacional desenvolveu-se em sentido diferente do direito nacional. Todavia, a realidade nos mostra que as regras são obrigatórias; há pressão geral para que sejam acatadas, e sua violação implica $\in m$ compensaçāo, represálias e contramedidas. Estas diferenças, no entanto, demonstram que não se pode concluir simplesmente que o Direito Internácional não é Direito porque não tem sanções, organizadas, sobreturo se cosiderarmos que o seu contexto é diferente (Pág. 271). 
A idéia de obrigação e soberania dos Estados é outra questão a ser considerada.

Na verdade, "Em toda sociedade, composta de indivíduos ou de Estados, o que é necessário ou suficiente para que as palavras de uma promessa, acordo ou tratado, façam surgir obrigações, é que as regras que assim o estabelecem e que especificam um proce. đimento para estes acordos que auto-obrigam, sejam geralmente acatadas, sem que se exija que o sejam de modo universal" (Pág. 278)

No caso de um Estado novo ou de um Estado que adquire território com orla marítima, por exemplo, observa-se que precisam aderir às normas existentes. Assim, pode-se verificar que o Direito Internacional é muito mais convencional e funciona pela observância às normas já existentes.

\section{O DIREITO INTERNACIONAL E A MORAL}

Em sua forma, o Direito Internacional se assemelha às regras primárias de obrigação, embora seu conteúdo seja bem distinto das regras da sociedade primitiva, e muitos de seus conceitos, métodos e técnicas, sejam iguais ao do moderno direito nacional. Os juristas, no entanto, costumam, ao comparar o direito nacional e o Internacional, considerar este último como sendo "moral".

No que toca ao direito nacional e à moral são destacadas por HART algumas diferenças substanciais: os Estados reprovam condutas imorais e elogiam-se ou elogiam os outros que se pautam pela moral internacionai̇; porém não significa que este direito é moral. Nas relações entre os Estados há estágios intermediários entre o que é claramente Direito e o que é claramente moral, como é o caso das regras que regem a cortesia internacional (no que toca aos diplomatas, por exemplo, as franquias aduaneiras) (Pág. 282).

O principal argumento é o seguinte: tanto as regras do direito nacional, quanto as do Direito Internacional são frequentemente indiferentes à moral. Podem existir por conveniência ou por necessidade, o que vale dizer que o direito embora possua muito do que é importante para a moral, pode conter regras de outra natureza, que são estranhas à moral. Foi justamente o respeito às formas e aos detalhes que levou aos excessos do formalismo e do legalismo (algo que é estranho à moral!).

No Direito Inernacional tais normas que se dedicam aos "detalhes" também são necesśárias, o que é próprio das regras jurídicas, e que é inadmissivel nas morais. 
Por outro lado, ainda que as normas jurídicas possam alterar práticas morais no grupo, a idéia de uma lei que sancione ou derrogue regras morais é absiriria.

"A moral é critério último mediante o qual são avaliadas as ações humanas (legislativas ou de outro tipo)" (pág. 284). Nada há na natureza ou na função do Direito Internacional que seja analogicamente incompatível com a idéia de que as regras poderiam estar submetidas a modifıcação por via legislativa; a ausência de uma lei não é mais que a ausência que muitos concebem como um defeito que um dia será sanado" (Pág. 284).

Um outro argumento que é sempre levantado é no sentido de que as regras de Direito Internacional têm que descansar na convicção de que os Estados têm a obrigação moral de obedecê-las (pág. 284). Embora possa haver tal sentimento de obrigação moral, é difícil ver porque ou em que sentido o mesmo tenha que existir como uma condição de existência do Direito Internacional. A prova de que existem regras obrigatórias em uma sociedade qualquer é simplesmente que elas são concebidas desta maneira e que funcionam como tais. $\mathrm{E}$ não poderiam continuar existindo se uma maioria preponderante não as aceitasse e cooperasse de forma voluntária para sua manutenção. Também é verdade que a pressão exercida sobre quem as transgride ou ameaça transgredir é fraca.

Sem dúvida, a adesão ao direito pode não estar motivada por sentimento difundido de que é moralmente obrigatório conformar-se a ele, pode estar njotivado por cálculos de interesses mediatos, pelo desejo de continua: uma tradição ou por uma preocupação desinteressada pelos demais. Não parece haver nenhuma boa razão para assinalar algum destes motivos como uma condição necessária da existência do direito entre os indivíduos ou entre os estados (Pág. 286).

\section{ANALOGIAS DE FORMA E DE CONTEÚDO}

Numa dimensão inocente, a estrutura formal do Direito Internacional, que carece de leis, de tribunais com jurisdição obrigatória e de sanções oficialmente organizadas, parece muito diferente da do direito nacional. Assemelha-se na forma, como vimos, ainda que de modo algum, quanto ao conteúdo. Uma das diferenças notórias, por exemplo, entre o direito riacional e o Internacional é que o primeiro diferentemente do segundo, usualmente não reconhece validez a acordos arrancados à força (como acontece, por exemplo, em tratados assinados após guerras, que implicam em diminuição da soberania de um povo...). 
No Direito Internacional, por exemplo, a Corte Internacional e a sua predecessora, a Corte Permanente de Justiça Internacional tiveram as suas decisões cumpridas pelas partes, como se isto compensasse o fato de que no direito nacional nenhum Estado pode ser levado ante tais tribunais internacionais sem consentimento prévio...

Há, no entanto, uma certa analogia formal entre o Direito Internacional e direito nacional que merece algum exame. Kelsen e muitos técnicos modernos insistem em que a semelhança entre Direito Internacional e interno é o fato de que possuem uma "norma fundamental", a que denominamos regra de reconhecimento (pág. 288), o que determina a validez de outras regras do sistema, e em virtude da qual as regras constituem um sistema único. O ponto de vista oposto é de que esta analogia é falsa: o Direito Internacional consiste simplesmente num conjurto de regras primárias de obrigação separadas, que não estão unidas desta maneira (pág. 288). Trata-se, segundo a termilogia usual dos internacionalistas, de um conjunto de regras consuetucinárias, uma das quais é a da força obrigatória dos tratados. Um dos princípios é do pacta sunt servanda, que já foi abandonado pela maioria dos teóricos e substituído por outro: "os estados devem conduzir-se como estão acostumados a fazer".

HART não discute o mérito desta ou daquela proposta, ao contrário, prefere lançar uma indagação: Por que temos de fazer esta pressuposição a priori (porque é o que ela é) e prejulgar assim a respeito do caráter efetivo das regras de Direito Internacional? Porque é concebível que uma sociedade pode conviver segundo regras que impõem obrigações a seus membros, ainda quando elas são simplesmente consideradas como um conjunto de regras separadas, que não estão unidas por nenhuma regra básica, nem derivam sua validez dela. É óbvio que a mera existência de regras não implica a existência de tal regra básica. São regras que formam um conjunto e não um sistema (288).

Há, por outro lado, uma série de perguntas que podem ser feitas sobre um conjunto de regras, como, por exemplo, origem histórica, influências causais que determinaram o crescimento das regras; o seu valor para os que vivem sob sua égide etc. A diferença é que a aceitação é muito importante para um conjunto de regras, porém se se trata de um sistema, antes de ser efetivamente ditiada podemos dizer que será válida se satisfaz os requisitos da regra de recohecimento (pág. 290).

"As regras de estrutura simples, como a regra básica dos sistemas mais avançados, são obrigatórias se são aceitas e funcionam como tais" (Pág. 290). Tal verdade pode ser obscurecida pela verdadeira ânsia de encontrar-se unidade e sistema onde efe- 
tivamente não existem (Pág. 290). Tanto assim é que a afirmação: "os estados devem conduzir-se como estão acostumados a 1azê-lo", nada mais é que afirmar que aqueles que aceitam certas regras devem também observar uma regra que diz que as regras devem ser observadas. Isto é uma mera redundância inútil" (Pág. 291).

Não há regra básica que estabeleça critérios de validez para o Direito Internacional, que as regras que existem têm uma natureza operativa e constituem um conjunto de regras, entre as quais estão as que estabelecem a força obrigatória dos tratados.

As analogias que existem entre o direito nacional e o Interna. cional são de função e conteúdo, e não de forma! (Pág. 292). As de função tornam-se claras quando refletimos sobre as maneiras em que o Direito Internacional difere da moral; as de conteúdo consistem no campo de princípios, conceitos e métodos que são comuns ao direito nacional e Internacional e fazem que a técnica dos juristas seja livremente transferível de um a outro (Pág. 292). 